In the fashion of the times, the author concedes that, in this book, the full story has not been told. Thus, where he forcefully demonstrates that economic changes to do with entrepreneurialism and money threaten the fabric of Inuit life in Kangersuatsiaq, we want to invite him to attempt a comparably hard-nosed analysis of what exactly underpins the Inuit institutional forms and customs that are in such jeopardy. To simply say (for example) that the Kangersuatsiaq kinship system exists in order to sustain a sense of community is surely a partial account: what needs to be asked is why this sense of community (which occurs universally?) is, in Kangersuatsiaq, delivered by this distinctive body of kinship ideas, and not by some other. A possible topic for the author's next book! (David Riches, Department of Social Anthropology, University of St. Andrews, St. Andrews, Fife KY169AL.)

\section{A HISTORY OF THE ORIGINAL PEOPLES OF NORTHERN CANADA (REVISED EDITION). Keith J. Crowe. 1991. Montreal and London: McGill-Queen's University Press. 248 p, illustrated, soft cover. ISBN 0- 7735-0880-5. £14.95.}

As the jacket correctly proclaims, this work has been one of the most readable and balanced accounts of the history and culture of Canadian northern peoples for more than 15 years. Casual readers, native students, and university undergraduates have been well served by the first edition of 1974, and a new generation of readers should welcome the revised edition of this standard text.

The revised edition does not differ substantially from the original. A quick comparison reveals that some archaeological periodizations have been changed and a few names and figures have been corrected in the first 10 chapters - but the changes have been so slight that even the page numbers have remained the same. An 18-page epilogue has been added to update the material to 1990 . Perhaps most significantly, the appendix offering the names and addresses of native political, cultural, and commercial organizations has been completely expanded and updated. The bibliography, however, has only been updated by 21 new entries for the past 17-year period.

It is a credit to the author that after 17 years his presentation of the history, politics, and culture of northern native people has not become dated. Crowe's careful selection of terminology and apt use of ethnonymns have kept pace with contemporary usage. The cultures of native peoples are presented in a manner that makes their traditions and customs appear to be a matter of common sense rather than curious and exotic. Foreign traders, missionaries, and administrators are presented in terms of their varied national origins and with a critical account of their strengths and weaknesses. At several points, the spiritual world of native peoples, as well as tales of contact with foreign traders and warfare between native groups, are based closely on accounts from folklore. Most impressive is the attention given to women as leaders and as indispensable partners in economic production and trade. The critical description of missionary and government practice in all regions of the Canadian north, and in comparison to circumpolar countries, is still an important introduction for beginners.

It is unfortunate that the epilogue on land claims, economic development, education, and other socio-cultural developments does not match the thoroughness of the original 10 chapters. First, it does not intermesh smoothly with the concluding chapters of the original text. For example, in the latter chapters certain organizations and projects (like COPE, or the James Bay 'scheme') are described as current concerns, while in the epilogue they are placed firmly in the past. One is given the impression that the Alaska Native Land Claim Settlement (in chapter 10) was an impetus for subsequent claims (in the epilogue), while forums such as the Berger Inquiry are downplayed. Second, there are significant omissions, ranging from simple facts on the size of the territories received and the dollar-value of compensations won through land claims to an account of the important constitutional debates on self-government for native people. (One should mention, on the positive side, that the controversy over the practice of 'extinguishment' of aboriginal rights is given an appropriate emphasis.) Finally, an index would have been a helpful addition. (David G. Anderson, Scott Polar Research Institute, Lensfield Road, Cambridge CB2 1ER.)

TRACE METALS AND FLUORIDE IN BONES AND TEETH. Nicholas D. Priest and Frank L. Van De Vyver (editors). 1990. Boca Raton, Ann Arbor, Boston: CRC Press. 390 p, illustrated, hard cover. ISBN 0-84936190-7. £154.00.

CRC Press, the American publishing company, is best known for its series of authorititive scientific handbooks, among the most-noted being the annual CRC handbook of chemistry and physics. CRC Press also has a tradition of publishing medical and scientific textbooks designed to be comprehensive introductions to specialist fields of study for researchers from a wide variety of disciplines. Trace metals and fluoride in bones and teeth is a collection of self-contained papers that includes descriptions of analytical techniques; the metabolism, chelation, toxicity, and distribution of trace elements and fluoride in animal bones and teeth; and the application of this knowledge to archaeological remains. The book is edited and written by eminent American and European specialists in the fields of medicine and dentistry, bone metabolism, nuclear magnetic resonance, toxicology and radiation research, palaeontology, physics, and bioengineering, and is designed to be of relevance to researchers in fields as diverse as biochemistry, radiation biology, geology, medical sciences, industrial hygiene, anthropology, archaeology, and palaeontology. Therefore, although the book is not directed toward polar research, and reference to Arctic peoples is only made twice (page 201 on lead concentrations in the teeth of North Slope Alaskan Inuit, and page 361 on increased strontium levels in the bones of Inuit subsisting on marine foods), it is an excellent source of information for anyone wishing to conduct analysis on the 
metals and fluoride content of the bones and teeth of human and animal populations in the polar regions.

The contributions from 14 authors vary considerably in style and approach. Some chapters - for example, 'A history of heavy metal contamination of human bones' and 'The accumulation of trace metals in bone during fossilisation' - are essay-like in form, and may be read easily in their entirety. Other chapters, such as 'Aluminum accumulation in bone,' comprise short sections that overlap in content and are repetitive when read from beginning to end. However, when viewed in isolation, these chapters form a series of concise, self-contained units that facilitate easy access to the material for reference purposes; this is especially relevant since the book seems to be intended primarily for use as a reference text, and few would need to read it from cover to cover.

Enhancing the reference value of the book is quick and easy access to the relevant information via the detailed contents pages at the beginning of each chapter, which list various sections and subheadings. The index, on the other hand, is rather variable in quality. For example, aluminium has the best part of nine columns of the index devoted to it, from its accumulation, distribution, and metabolism to evidence relating to its toxicity and its role in bone disorders. Zinc, alternatively, only receives one entry in the index (page 1, where only passing reference is made to the element), despite the fact that it is referred to throughout chapters 7 and 13 and has a three-page exclusive section in chapter 11 . That large sections of the book appear not to be included in the index seriously detracts from its value as a reference source.

The scope of the book is wide-ranging, and there is a balance between chapters concentrating solely on one element - for example 'Cadmium in human bones and teeth' or 'The metabolism and effects of fluoride' - and those that deal with physiological or biochemical processes and use data from studies of various trace metals to make comparisons, such as two chapters on the metabolism of essential and non-essential trace elements and that entitled 'The in vitro and in vivo uptake of trace elements by hydroxyapatite.'

Different aspects of particular elements can be found throughout many of the chapters in the book, which I found made the reading more interesting. Lead, for example, is included by several authors. Zbigniew Jaworowski, in the chapter entitled 'A history of heavy metal contamination in human bones' notes that 'lead has been studied in man and in the environment much more intensely than other heavy metals' (page 176), and points out that lead is not the most toxic of the anthropogenic heavy metals, that its output from industrial and domestic processes has not increased as rapidly as other potentially damaging elements, and that, unlike some other elements such as fluoride, the difference between 'normal' levels and toxic levels is comparatively large. Having made the observation that lead has received an unprecedented amount of attention compared to other elements, Jaworowski gives a brief review of lead analysis on historical populations (pages 181-86). In the next chapter, Maurice V. Stack reviews lead concentrations and kinetics in human hard tissues and the analytical techniques commonly used for assessing such concentrations. Lead accumulation in both human and animal populations is also reviewed by Stanley Wallach and Art Chausmer (pages 240-43); their references to lead do not appear in the index, although they might usefully have been included under 'lead levels in human bones' and 'lead intake, human.'

Lead in the environment has been granted particular importance in the polar literature. It has been found in unexpectedly high levels in Antarctic seawater (Lee and others 1990), and, with a wide range of other contaminants, in recent ice cores from Greenland and the Antarctic (Delmas and Legrand 1989). However, as yet there has been comparatively little research on lead concentrations in the hard tissues of Arctic and Antarctic animals (most heavy metal contamination analysis being conducted on soft tissues), although analysis of bones and teeth may yield important results that relate to the elevated levels that appear to be present in these environments. In terms of lead levels in human bones in the Arctic, Grandjean's (1989) analysis of the fifteenth century Qilakitsoq mummies included an examination of lead in the trabecular part of the vertebrae, and Beattie (1985), in his controversial study of skeletons from the crew of the Franklin expedition of $1845-48$, suggested that elevated lead levels may have resulted in lead intoxication of the crew.

This book underlines the need for further research into the heavy metal content of bones and teeth from the polar regions. Because bones and teeth are durable and bones play an important role in the storage and disposal of a variety of essential and non-essential heavy metals, they offer advantages over soft tissues, and, in archaeological samples, are often the only evidence of past populations. The stated aim of the book is 'to promote the information exchange which is commonly lacking by describing and reviewing a variety of research areas which are considered likely to be of widespread interest. It is hoped that readers will find parallels between work in their own field of study... which they may later exploit to their own advantage' (page 1). The aim has undoubtedly been realised in the selection of subjects and the choice of authors from a wide range of disciplines; hopefully the book will encourage and excite further research on heavy metals in teeth and bones from the polar regions so that this potentially valuable source of information may be exploited. (E. Cruwys, Scott Polar Research Institute, Cambridge CB3 9BB.)

\section{References}

Beattie, O. 1985. Elevated bone lead levels in a crewman from the last Arctic expedition of Sir John Franklin (1845-1848). In:Sutherland, P.D. (editor). The Franklin era in Canadian Arctic history. Ottawa: National Museum of Man, Mercury Series, Archaeological Survey of Canada Paper 131: 141-48.

Delmas, R.J., and M. Legrand. 1989. Long-term changes in the concentrations of major chemical compounds 
(soluble and insoluble) along deep ice cores. In: Oeschger, H., and C.C. Langway, Jr (editors). The environmental record in glaciers and ice sheets. New York and Chichester: John Wiley \& Sons: 319-41.

Grandjean, P. 1989. Bone analysis: silent testimony of lead exposures in the past. Meddelelser om Grenland, Man \& Society 12: 156-60.

Lee, S.H., K.T. Kim, and S.H. Kim. 1990. Trace metals in the surface water of Maxwell Bay, King George Island, Antarctica. Korean Joumal of Polar Research 1 (2): 1115.

NORTH POLE, SOUTH POLE: JOURNEYS TO THE ENDS OF THE EARTH. Bertrand Imbert. 1992. London: Thames and Hudson. 192 p, illustrated, soft cover. ISBN 0-500-30010-0. $£ 6.95$.

The recently released 'New Horizons' series of books is claimed by its publisher to provide 'the perfect introduction to a topic: instructive, stimulating, intriguing.' By emphasizing photography and illustration, mostly reproduced in full-colour, the books attempt to attain the "universal range of an encyclopaedia, the captivating beauty of an artbook, with in-depth coverage of each subject.'

North Pole, South Pole is the series' laudable attempt to capture in one pocket-sized $(18 \times 12.5 \mathrm{~cm})$ paperback the entirety of the history of polar exploration. Written by Bertrand Imbert, the former director of the French Antarctic expeditions in the International Geophysical Year (all of the titles in the series have French authors), the book has two major sections. The first, covering two-thirds of the pages, is an overview of polar exploration from the sixteenth to the twentieth century, with special emphasis on the science of the past 50 years. The second part, entitled 'Documents,' notes interesting aspects of polar history and science, including Scott's message to the public, some of Hurley's photographs from Shackleton's expedition in Endurance, a review of the Northern Sea Route, an introduction to the study of Antarctic ice, and information about the Antarctic Treaty. There are also a chronology of polar exploration and science, a brief glossary of terms, suggestions for further reading, and an index.

This is a popular, non-academic account directed at a large non-specialist audience. It is not referenced, although it gives an extensive list of its illustrations and their credits. The artwork is indeed what makes the book special. There is a large variety of photographs, portraits, landscape paintings and drawings, and excerpts from books, newspapers, and magazines. Many of them are the standard pictures - including that of Scott's party at the South Pole - but others are more uncommon, such as a drawing of a feuding Cook and Peary from a 1909 edition of Petit Journal.

Polar exploration is certainly made interesting to the uninitiated, but the book suffers from several flaws in presentation. There are not nearly enough detailed maps, so that it would be difficult for someone with no background in the field to follow exactly what happened during, for example, the Franklin searches or the Jeannette expedition. Place-names are generally given in English, rather than in the form officially used within the country concerned, making it difficult to locate on other modern maps places such as 'Northeast Land' (Nordaustlandet). That the crossheads in the text are in the present tense, while the rest of the book is in the past tense, is also confusing.

There are also significant factual errors. For example, it is stated that HMS Investigator was trapped in the ice for three years and did not return to England until 1853; in fact, McClure abandoned his ship in 1854 and the crew returned home on other naval vessels. There is occasional confusion in the use of names, which suggests a lack of familiarity with the topic: Nansen's companion Johansen, referred to in the book as 'Frederick,' did not go by that, his first name, but rather by Hjalmar; similarly, Nordenskiold did not normally use his first name, 'Nils,' by which he is referred to in this account, but was known universally as Adolf Erik. In addition, the most avid sponsor of Frederick Cook in 1909 was The New York Herald, not the Herald Tribune (which it became in 1926).

There also could be questions about the book's emphases on specific expeditions or individuals. For example, three pages are devoted to Nobile's Italia expedition, whereas only two paragraphs are given to Amundsen's completion of the Northwest Passage in Gjøa, and no mention in the body copy is made of Greely's expedition to Lady Franklin Bay during the International Polar Year, Sverdrup's 1898-1902 expedition, or Bruce's Scouish National Antarctic Expedition. Likewise, John Rae is not mentioned by name in the section on the Franklin search, and Alfred Harmsworth is mentioned as one of a number of contributors to Scott's Discovery expedition rather than as the sponsor of the Jackson-Harmsworth Expedition.

Despite its weaknesses, this volume is the only introductory and inexpensive history of polar exploration that emphasizes photography and illustration more than words. As a historical account, it is no mitch for L.P. Kirwan's near-classic The white road, or for Pierre Berton's more recent (and more popular) The Arctic grail, but it could well interest a new set of young polar enthusiasts. (Beau Riffenburgh, Scott Polar Research Institute, Lensfield Road, Cambridge CB2 1ER.)

OUT OF THE CHANNEL: THE EXXON VALDEZ OIL SPILL IN PRINCE WILLIAM SOUND. John Keeble. 1991. New York: HarperCollins. 290 p, hard cover. ISBN 0-06-016334-8. \$22.95 (US).

The tragedy and ballyhoo of 1989 , when a silent spring came to Alaska's Prince William Sound and irate consumers were destroying their Exxon credit cards, will remain fresh in many minds. And if those images of oil-soiled otters chewing off their paws are in danger of fading, we now have the investigative journalism of novelist John Keeble, who flew north two weeks after the human and environmental calamity to cover the story for Village Voice.

The tale begins in Valdez, with a pinch of Alaskan history and the hazards of the local weather and topogra- 